Bartłomiej Oleszek

\section{Festiwal teatralny - między świętem a przesytem}

DOI: http://dx.doi.org/10.12775/LC.2018.026

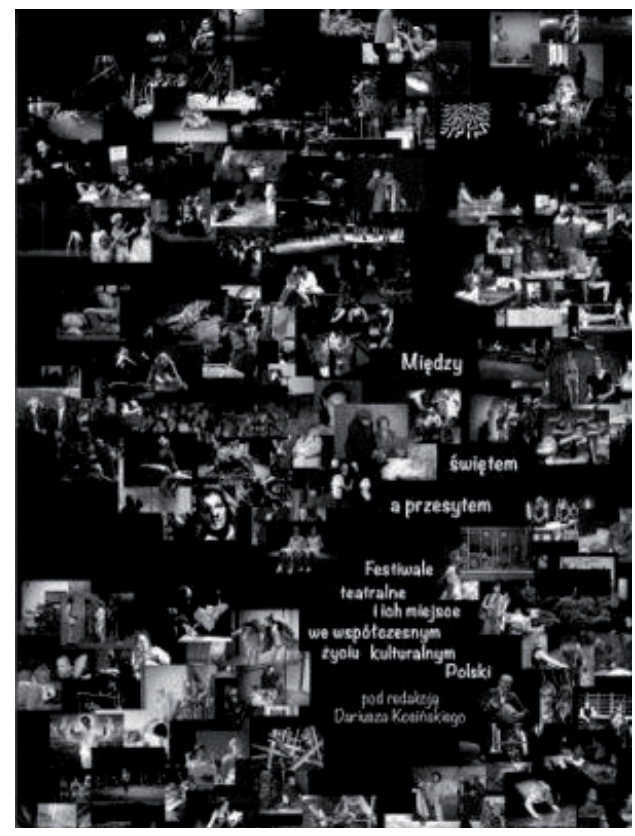

(5)

om Między świętem a przesytem: festiwale teatralne i ich miejsce we wspótczesnym życiu kulturalnym Polski nie jest jedynie dokumentacyjną refleksją nad polskimi przeglądami teatralnymi i ich miejscem w kulturalnym

* Teatrolog, absolwent studiów doktoranckich w Katedrze Kulturoznawstwa Uniwersytetu Mikołaja Kopernika w Toruniu (2017). E-mail: bartekoleszek@ gmail.com. krajobrazie kraju, nie jest zestawieniem prezentującym wyłącznie historię i repertuar poszczególnych przeglądów, festiwali czy konkursów. Jest publikacją, która wchodzi głębiej w problematykę obecności (i nadmiaru) festiwali w Polsce. Książka pod redakcją naukową Dariusza Kosińskiego poddaje również refleksji współczesną problematyczność festiwalu jako takiego, pyta o sens jego organizacji i aktualność świątecznego statusu, o współczesną kondycję przeglądów teatralnych w Polsce. Wychodzi też z ciekawej (o)pozycji - ulokowania problematyki sfestiwalizowanej polskiej sceny teatralnej właśnie między świętem, więc szczególnym momentem w kalendarzu kulturalnym, a przesytem, spowszednieniem owocującym utratą prestiżu. To napięcie stanowi pierwszy z najbardziej interesujących wątków tomu. Kolejny to niewątpliwie aspekt dokumentacyjny - w Między świętem a przesytem... opisano bodaj wszystkie najważniejsze przeglądy w Polsce, w wielu wypadkach skrupulatnie sportretowano zarówno idee założycielskie i ich ewolucję przez lata, jak również aspekty repertuarowe, organizacyjne i ekonomiczne. Jednak zawsze wydobywano z nich wiele więcej niż czystą chronologię, warunki finansowania i modele zarządzania, każdorazowo docierając do głębszych treści - choćby ich znaczenia dla miast czy całego kraju.

Publikacja wydana w Szczecinie w 2016 roku jest owocem konferencji naukowej Święto czy konieczność? Festiwale teatralne $i$ ich miejsce we wspótczesnym $\dot{z} y$ ciu kulturalnym Polski, która odbyła się w kwietniu 2015 roku w Szczecinie. Sesja towarzysząca jubileuszowej pięćdziesiątej edycji Przeglądu Teatrów Małych Form „Kontrapunkt” zgromadziła zarówno naukowców i krytyków, jak również dyrektorów najważniejszych przeglądów teatralnych w kraju. Przesunięcie problematyki tomu względem debat (z pytania „Święto

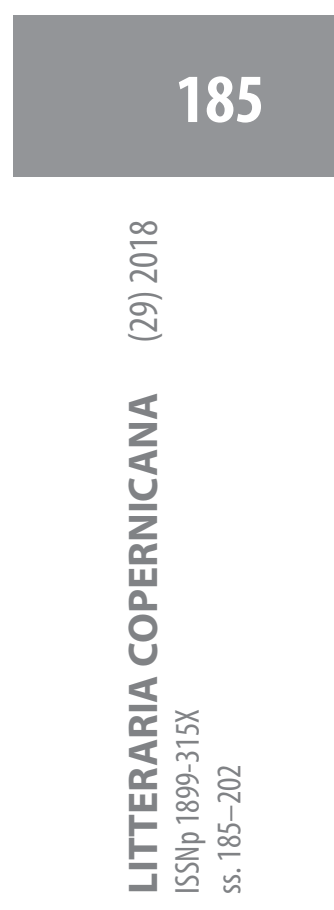


czy konieczność?” na „Między świętem a przesytem"), o czym pisze we wprowadzeniu Dariusz Kosiński, kieruje uwagę czytelników na interesującą kwestię spowszednienia festiwalu, powolnego odbierania mu tego, co stanowiło o jego wyjątkowości, czyli wyjścia poza ramy zwyczajnego sezo$\mathrm{nu}$ teatralnego ku świątecznej uczcie dla teatromanów, okazji do zobaczenia zagranicznych, a nawet egzotycznych zespołów. Monografia kieruje uwagę właśnie na dostrzeżoną $\mathrm{w}$ konferencyjnej dyskusji perspektywę przesytu, nadmiaru przeglądów w Polsce:

Tworząc program konferencji wychodziliśmy z założenia $[\ldots]$, że festiwale przez swoją wielość, różnorodność i szczególne znaczenie przestały być czymś wyjątkowym i specjalnym, lecz stały się niemal codziennością. Przestały być w polskim życiu teatralnym wyjątkiem, a stały się tego życia oczywistą i powszechną formą, wprowadzającą $\mathrm{w}$ jego obręb ważne zmiany, które domagają się namysłu, także krytycznego. Temu namysłowi poświęcone są teksty składające się na niniejszą książkę (Kosiński 2016b: 9).

Przesunięcie akcentu potwierdza otwierający tom tekst Doroty Buchwald, w którym autorka przytaczając skrupulatnie zebrane i ciekawie zaprezentowane statystyki, potwierdza słuszność takiej koncepcji kompozycyjnej. To zapowiadane przez redaktora we wstępie „trzęsienie ziemi”, którym faktycznie jest tekst dyrektorki Instytutu Teatralnego im. Zbigniewa Raszewskiego. Autorka w szkicu Wspótczesne festiwale $w$ Polsce. Typologia i geografia najpierw zgodnie $\mathrm{z}$ tytulem artykułu prezentuje kilka ujęć systematycznych polskich festiwali według różnych kryteriów: pod względem charakteru (jednego aktora, branżowe, tematyczne, interdyscyplinarne), formy (punktowe, liniowe, crossowe, podróżujące) czy celu (z misją kulturową, komercyjne). Jednak najbardziej uderzające są przywoływane w dalszej części statystyki, które pokazują lawinowy przyrost festiwali w Polsce i to $\mathrm{w}$ ostatnich latach. W sezonie 2013/2014, który autorka analizuje, odbyło się 429 festiwali w 145 miastach (65 w samej Warszawie). W zestawieniu z sezonem 2008/2009, w którym odbyło się o 85 imprez mniej, obrazuje to niespotykane dotąd przyspieszenie. Jednak ciekawe liczby i dane to jedna strona artykułu Wspótczesne festiwale..., druga to pokazanie szerszego problemu, który one sygnalizują (choćby określania jako festiwal innych komercyjnych imprez, np. gastronomicznych). A także wyjścia, którego nie ma, bo przecież festiwale teatralne powinny istnieć i ich redukcja (jeśli w ogóle możliwa) nie jest wyjściem z tej sytuacji.

Szerzej ten problem pokazuje w swoim tekście Jacek Kopciński. Jednak refleksja, dla której punktem wyjścia są ciekawe spostrzeżenia m.in. socjologa Tomasza Szlendaka i innych badaczy mówiących o „festiwalizacji życia kulturalnego” stoi w kontrze do tekstu Doroty Buchwald. Bo o ile wirusa festiwalozy dostrzegają wszyscy, to wcale nie powinniśmy - zdaje się pisać autor - rozpaczliwie szukać antidotum. Warto natomiast przyjrzeć się mutacjom spowodowanym przez ów wirus: powstaje nowy typ widza, nowe produkcje festiwalowe oraz nowe modele zarządzania ( $\mathrm{z}$ wymaganiami organizatorów i mecenasów). Jak słusznie konkluduje Kopciński, „globalizacja nie musi oznaczać makdonaldyzacji” (Kopciński 2016: 31). Pokazują to najdobitniej festiwale lalkarskie ( $w$ tomie opisane przez Halinę Waszkiel), które straciły monopol na prezentację przedstawień na rzecz rozszerzających swoje formuly innych przeglądów. Co z jednej strony osłabiło status festiwali teatrów lalek, ale $\mathrm{z}$ drugiej wzbogaciło programy innych imprez. 
Wspomniane teksty znalazly się w pierwszej części tomu zatytułowanej Między świętem a przesytem, stanowiącej teoretyczny wstęp pokazujący różne perspektywy interpretowania takiej sytuacji w Polsce. Obok wprowadzenia w rozważania pokazują właśnie rozmaite diagnozy stawiane teatrowi cierpiącemu na festiwalozę jeśli zostać przy tej medycznej metaforze groźnej choroby, której objawy w ostatnich latach znacząco się nasiliły (a która metafora chyba nie do końca oddaje skalę i problematykę zjawiska). Jak to zwykle bywa przy interpretacjach medycznych, można wróżyć pesymistycznie (prognozując rychłą śmierć idei festiwalu jako święta), optymistycznie (wielość rodzić może unikatową różnorodność) lub ważyć ocenę, lawirując między opiniami specjalistów.

Pozostałe części szczecińskiej publikacji to Między centralizacją a lokalnościa (pokazujące napięcie między tym, co obecne na najważniejszych scenach i festiwalach, a tym, co „warszawskie” i „prowincjonalne" - Olkusz 2016: 66-67), Miasto przeglada się $w$ swoich festiwalach (szczególne relacje miast-gospodarzy ze swoimi festiwalami) oraz Dramaturgie i narracje festiwali (refleksja nad festiwalem jako takim). Wychodząc poza ten układ - czytelnie i wyraziście organizujący bogaty materiał, jakiego zwykle dostarczają monografie wieloautorskie - chciałbym skoncentrować się na wątkach stanowiących wspólny mianownik wielu tekstów. Drugim niezwykle intrygującym tematem tomu Między świętem a przesytem ..., po opozycji święto-przesyt, jest ciekawie zapisana $\mathrm{w}$ wielu tekstach idea festiwalu jako takiego. Kiedy pytanie o jego współczesny status jest w mocy, kieruje debatę na ciekawe tory i prowadzi do interesujących wniosków.

Pokazują to z jednej strony szkice poświęcone przeglądom lokalnym, wpływom festiwali na krajobraz kulturalny miasta czy regionu. Górny Śląsk przez pryzmat ruchu festiwalowego portretuje $w$ interesującym tekście Aneta Głowacka. W jej opisie przeglądy teatralne (i nie tylko) pokazują ożywienie tkanki regionu i starania o przełamanie stereotypu o ziemi wyjałowionej ciężkim przemysłem. Wykuty $\mathrm{z}$ trudem Ogólnopolski Festiwal Sztuki Reżyserskiej „Interpretacje” czy Międzynarodowy Festiwal Sztuk Performatywnych „A Part” skutecznie rewitalizują i rebrandingują Górny Śląsk. Podobnie jak ciekawie opisane sceny letnie, które - choć obecne w wielu polskich miastach - zwykle są pomijane $\mathrm{z}$ jednej strony ze względu na nierówny repertuar, z drugiej ze względu na pozasezonowy okres teatralnego rozprężenia. Jednak uwaga poświęcona śląskim letnim przeglądom pokazuje interesujące napięcia. Jak w wypadku opisywanego przez Głowacką Wakacyjnego Przeglądu Przedstawień organizowanego od 1999 roku w chorzowskim Teatrze Rozrywki. WPP z jednej strony prezentuje repertuar wakacyjny, z drugiej gościł już spektakle Moniki Strzępki i Pawła Demirskiego czy przedstawienia Teatru Polskiego w Bydgoszczy. Kiedy piszę te słowa, trwa wielka batalia o prezentację podczas 19. odsłony chorzowskiego festiwalu Klątwy w reżyserii Olivera Frljicia. To pokazuje, że teatr nie zawiesza swojej siły oddziaływania na czas wakacji. I nie traci jej w ośrodkach powszechnie niekojarzonych $\mathrm{z}$ intensywnym życiem teatralnym.

Podobny proces w historii Łodzi interesująco opisała Małgorzata Leyko. Kiedy w szeroki kontekst kulturalnego powojennego dojrzewania miasta (czyli właściwie po roku 1949, kiedy „zaczęli wyjeżdżać do Warszawy wojenni rozbitkowie, którzy znaleźli w Łodzi chwilową przystań” - Leyko 2016: 94) wpisuje najpierw teatry studenckie i ferment kulturalny w środowisku akademickim, a następnie rolę Łódzkich Spotkań Teatralnych (i Baletowych) - to 
wówczas w teatrze jak w zwierciadle odbija się historia miasta. W artykule zatytułowanym Miasto przyglada się festiwalom widać niezwykle wyraziście wpływ teatru i festiwalu na tożsamości miasta, przecięcia - nawet symboliczne - jak w poniższym fragmencie.

W swoim najlepszym okresie festiwal był postrzegany jako „wyspa artystycznej wolności”, ale był także wyspą w pejzażu miasta. Festiwal w grudniu 1970, napędzany wydarzeniami na Wybrzeżu, tworzył zwartą wspólnotę izolowaną od tego, co na zewnątrz. Jeśli dochodziło do spotkań między uczestnikami festiwalu a mieszkańcami miasta, to zazwyczaj nad ranem w tramwajach, którymi wspólnie przemierzali miasto studenci wyczerpani nocnymi dyskusjami o sprawach wówczas najważniejszych i wracające z nocnej zmiany włókniarki (ibid.).

Sprzęgnięcie miasta $\mathrm{z}$ festiwalem na przykładzie toruńskiego Międzynarodowego Festiwalu Teatralnego „Kontakt” pokazuje również Artur Duda. „Kontakt” w nadzwyczaj mocny sposób związał się $\mathrm{z}$ miastem choćby $\mathrm{w}$ wymiarze przestrzeni - Krystyna Meissner wyszła z festiwalem poza Teatr im. Wilama Horzycy. Od razu też uczyniła $\mathrm{z}$ niego najważniejszy przegląd $\mathrm{w}$ mieście, zostawiając $\mathrm{w}$ tyle festiwale w Baju Pomorskim czy Alternatywne Spotkania Teatralne „Klamra” w uniwersyteckiej Od Nowie. W artykule Idea i znaczenie Międzynarodowego Festiwalu Teatralnego „Kontakt” interesująco opisany festiwal (z korzeniami w FTPP, różnorodnym repertuarem, reżyserskimi odkryciami) wpisuje się w teatralną i performatywną historię miasta nakreśloną tu od przełomu XIX i $\mathrm{XX}$ wieku - już wówczas w Toruniu, niekoniecznie $\mathrm{w}$ teatrze, goszczono przyjezdne zespoły.

Jeszcze inne korzenie niż Łódź i Toruń miał Poznań. O poznańskiej „Malcie” w tek- ście Festiwal Malta: od sztuki jako narzędzia demokratyzacji do najbardziej rozpoznawalnej marki... (i $z$ powrotem?) pisze Joanna Ostrowska:

W 1990 roku władze Poznania, doprowadzając z okazji Kajakarskich Mistrzostw Świata do ponownego napełnienia wodą długiej i śmierdzącej rynny, której środkiem biegła rachityczna rzeczka Cybina, przywrócily miastu sztuczne jezioro Malta. $\mathrm{Na}$ potrzeby mistrzostw powstała cała infrastruktura w części miasta, która tak naprawdę nie funkcjonowała (zarówno faktycznie, np. brak komunikacji publicznej, jak i mentalnie) jako część Poznania. Obdarzeni kłopotem włodarze, na fali demokratycznych przemian, postanowili wezwać na pomoc ludzi sztuki, którzy przede wszystkim są tańsi niż wysokiej klasy specjaliści technicy. Tak więc to, co wydawało się nowatorskim pomysłem władz miasta, było w gruncie rzeczy realizacją starej, wypróbowanej strategii (Ostrowska 2016: 155-156).

Nie wchodząc głębiej w opis pozostałych miast i przeglądów (zawsze wnikliwie sportretowanych $)^{1}$, chciałbym dodać, że bardzo ciekawe $\mathrm{w}$ szkicach poświęconych poszczególnym miastom są fragmenty dotyczące osobistych związków poszczególnych autorów z ich „własnymi” festiwalami. Takie uwagi, często usuwane z naukowych opracowań, tu słusznie ocalały, pokazując, jak ważną rolę w doświadczeniach teatralnych odgrywają takie przeglądy, jak często naukowe ścieżki teatrologów wykuwały się $\mathrm{w}$ biurach prasowych festiwali, podczas paneli, debat, pospektaklowych i kuluaro-

\footnotetext{
1 Pozostałe to: Szczecin (R. Cieślak, Ta (nie) znośna przyjemność Formy! O społecznym i kulturowym potencjale festiwalu teatralnego w Szczecinie), Lublin (Jarosław Cymerman, Konfrontacje z miastem. Festiwale teatralne w Lublinie), Kraków (Monika Kwaśniewska, Od Showcase do festiwalu autorskiego), Wrocław (Tomasz Kireńczuk, Festiwal jako performans, czyli narracje "Dialogu”).
} 
wych rozmów czy w trakcie przerw, podróży i odwiedzin nowych miast (co stanowiło zagłębie anegdot, którymi żyją festiwale). W rozmowach o ksztattach, ideach i formułach festiwali często ginie właśnie osobiste doświadczenie w kontakcie z serią przedstawień. Dlatego tak ciekawie - jak w artykułach Joanny Ostrowskiej czy Artura Dudy piszących o „swoich” festiwalach - wypadają te właśnie ustępy.

Powracając do pytania o status festiwalu, warto spojrzeć na niego z jeszcze dwóch obecnych w książce perspektyw: teoretycznej i historycznej. Z pierwszego punktu widzenia o festiwalu mówi się jako pojedynczym performansie (Tomasz Kireńczuk), kompleksie performansów (Artur Duda) oraz festiwalu jako złożu performansów (Dariusz Kosiński). Ostatnią propozycję szerzej opisuje redaktor tomu $\mathrm{w}$ artykule Dramaturgia i performatywność festiwalu teatralnego:

Festiwal jest zespołem, złożem wielu performansów, należących do trzech grup wyróżnionych i opisanych przez Jona McKenziego: performansu artystycznego, organizacyjnego i technicznego. Zespolenie tych trzech typów performansu jest dla festiwalu kluczowe (Kosiński 2016a: 145).

Dramaturgię festiwalu Kosiński bada następnie $\mathrm{z}$ dwóch perspektyw: organizatora i widza. Pierwsza opera się na programie-scenariuszu (jedno- lub wielowątkowym, zawierającym elementy główne i towarzyszące, oficjalne i pozaprogramowe), drugi wskazuje na różne stopnie zaangażowania w festiwal, na różnych widzów uczestniczących w tym samym wydarzeniu. Ciekawym napięciem, które autor prezentuje, jest również balans między zespołami organizacyjnym i merytorycznym: pierwszy mówi „cokolwiek, byle sprawnie i efektownie”, drugi „jakkolwiek, byle znacząco”. To celne spostrzeżenie, które pokazuje, że ta walka jest wpisana w idee organizacyjne festiwalu. Pokazuje również, że zaburzenie po którejś ze stron tego równania zawsze rodzi nieprawidłowości (organizacyjne $\mathrm{w}$ przypadku niedopatrzenia z pierwszej strony, repertuarowe przy zbytniej uległości drugiej ze stron).

Historyczne ujęcia w ciekawy sposób, obok skrupulatnie zebranej materii dokumentacyjnej, odsłaniają z kolei korzenie rozrostu festiwali. I tak Zenon Butkiewicz w Komu potrzebne sa festiwale? wskazuje, że już w sezonie 1964/1965, w którym odbyło się pięć (!) festiwali, Ministerstwo Kultury i Sztuki w swojej diagnozie zauważyło m.in. „przesyt festiwali” (Butkiewicz 2016: 51). Pozwolę sobie wyliczyć dalej za autorem: 1970/1971 - kilkanaście imprez, 1988/1989 - 31, 1999/2000 ponad 50. Autor powołując się na Dragana Klaicia, konkluduje: „liczba festiwali w Europie od 1989 roku przez dziesięć lat wzrosła z pięciuset do trzech tysięcy" (ibid.). To ciekawe rozbudowanie problematyki wskazanej w teście Doroty Buchwald. Z innym jej aspektem - typologiami - koresponduje tekst Jana Ciechowicza, który obok idei, historii i podziałów festiwali proponuje trzy zbliżenia na przeglądy trójmiejskie: na gdański Festiwal Szekspirowski, sopocki Festiwal Teatru Polskiego Radia i Teatru Telewizji „Dwa Teatry” oraz gdyński Festiwal Polskich Sztuk Współczesnych „R@aport”.

Ze szkicem Jana Ciechowicza Typologia $i$ charakterystyka festiwali teatralnych (na przykładzie Polski Pótnocnej) wiąże się jeden ważny, a niemal nieobecny w tomie wątek (zaznaczony w tym tekście). Mianowicie przyłożenie pojawiających się $\mathrm{w}$ tomie pytań do festiwali i przeglądów teatru telewizji i teatru radiowego. Na przykład „Dwa Teatry" swoją formulą idealnie wpasowalyby się w problematykę zasadności festi- 
walu jako takiego. Ze skomplikowaniem pytań o ponowne prezentowanie spektakli już powszechnie znanych, osiągalnych i wyemitowanych $\mathrm{w}$ ogólnodostępnych przecież mediach, pojawiających się po emisji jako podcasty (słuchowiska) czy w systemie VOD (spektakle telewizyjne). Oba też oczywiście w pirackim obiegu. Czy zmiana stylu odbioru - z domowych odbiorników, komputerów czy smartfonów na sale kinowe, wspól-obecność w odbiorze - jest jedynym powodem istnienia „Dwóch Teatrów”? A może powinien ten festiwal iść tropem festiwalu internetowego, takiego jak np. akcja „Włącz teatr”. Wówczas tylko na jeden weekend otwarto dostęp do pakietu danych, zresztą bardzo atrakcyjnego. W jego ramach od 6 do 9 września 2012 roku w blokach tematycznych prezentowano $\mathrm{w}$ Internecie spektakle Andrzeja Wajdy, Grzegorza Jarzyny, Jana Klaty, Piotra Cieplaka, Jerzego Grzegorzewskiego, Krzysztofa Warlikowskiego, OPT „Gardzienice” czy Teatru Pieśń Kozła, a także oper Mariusza Trelińskiego. Umieszczone na serwerach Ninateki przedstawienia były dostępne dla widzów wyłącznie w dniach trwania festiwalu. Co wreszcie z produkcjami zrealizowanymi poza instytucją Teatru Telewizji i Teatru Polskiego Radia? Audiobook nagrany przez aktorów-amatorów to już słuchowisko konkursowe? Festiwal spektakli „Teatroteki”, który odbył się w lutym 2017 roku, również pokazuje, o czym na łamach „Teatru” pisała Kalina Zalewska (Zalewska 2017), konieczność zmiany myślenia o instytucjonalnym radiowym oraz telewizyjnym teatrze $\mathrm{i}$ - tym samym - festiwalu prezentującym te produkcje. A może wreszcie - patrząc przewrotnie, do czego zachęca tom Między świętem a przesytem... - „Dwa Teatry” to ostatni teatralny festiwal rozumiany jako święto? Jako unikatowe, jedyne spotkanie, na którym spektakle są prezentowane $\mathrm{w}$ dany sposób tylko raz?
$\mathrm{Na}$ zakończenie z recenzenckiego obowiązku muszę wspomnieć o mankamentach edytorskiej strony tej $\mathrm{z}$ wielu względów wartościowej książki. Z pewnością publikacja lepiej zaistniałaby (i byłaby przyjaźniejsza w lekturze) przy choćby kilku udoskonaleniach edytorskich, jak zwiększenie marginesów, czytelniejszy krój czcionki czy staranniej opracowane przypisy (bez indeksu górnego, wcięć akapitowych czasem trudno odnaleźć adres bibliograficzny, zwłaszcza internetowy). Szkoda też, że w Między świętem a przesytem... zabrakło ilustracji, grafik, diagramów czy plakatów, które $\mathrm{w}$ niejednym przypadku miały już całe wystawy i albumy (w książce znalazły się zaledwie dwie grafiki w tekście Roberta Cieślaka). Ginie również umieszczony na końcu tekst Anny Matras Festiwalowe dialogi po godzinach, będący ciekawym zapisem towarzyszących 50. „Kontrapunktowi” paneli dyskusyjnych z dyrektorami festiwali teatralnych. Fotorelacja $\mathrm{z}$ debat znacząco wzbogaciłaby ten tekst ciekawie podsumowujący całość materiału zebranego w tomie. Materiały, programy czy festiwalowe ulotki stanowią po latach cenne źródło informacji o oglądanych przedstawieniach, twórcach czy samym przeglądzie. Bezcenne z kolei są powstałe przy festiwalach opracowania naukowe. Dlatego warto poświęcać im więcej wydawniczej uwagi.

\section{Bibliografia}

Butkiewicz, Zenon 2016. „Komu potrzebne są festiwale?”. W: Dariusz Kosiński (red.). Między świętem a przesytem. Festiwale teatralne i ich miejsce we współczesnym życiu kulturalnym Polski. Szczecin: Teatr Pleciuga.

Kopciński, Jacek 2016. „Festiwalizacja teatru?”. W: Dariusz Kosiński (red.). Między świętem a przesytem... Szczecin: Teatr Pleciuga. 
Kosiński, Dariusz 2016a. „Dramaturgia i performatywność festiwalu teatralnego". W: Idem (red.). Między świętem a przesytem... Szczecin: Teatr Pleciuga.

- 2016b. „Wprowadzenie w pola napięć”. W: Idem (red.). Między świętem a przesytem... Szczecin: Teatr Pleciuga.

Leyko, Małgorzata 2016. „Miasto przygląda się festiwalom”. W: Dariusz Kosiński (red.). Między świętem a przesytem... Szczecin: Teatr Pleciuga.

Olkusz, Piotr 2016. „Splendor, prestiż, europejskie profity i wielka polityka' - czyli festiwal $\mathrm{w}$ Warszawie $\mathrm{w}$ erze nowej centralizacji”. W: Dariusz Kosiński (red.). Między świętem a przesytem... Szczecin: Teatr Pleciuga.

Ostrowska, Joanna 2016. „Festiwal Malta: od sztuki jako narzędzia demokratyzacji do najbardziej rozpoznawalnej marki... (i z powrotem?)”. W: Dariusz Kosiński (red.). Między świętem a przesytem... Szczecin: Teatr Pleciuga.

Zalewska, Kalina 2017. „Ucieczka od realizmu”. Teatr 4. 